\title{
Evaluation of soil erosion rates in the southern half of the Russian Plain: methodology and initial results
}

\author{
Valentin Golosov ${ }^{1,2}$, Artem Gusarov ${ }^{1}$, Leonid Litvin ${ }^{2}$, Oleg Yermolaev ${ }^{1}$, Nelly Chizhikova ${ }^{1}$, \\ Guzel Safina $^{1}$, and Zoya Kiryukhina ${ }^{2}$ \\ ${ }^{1}$ Kazan Federal University, Kremlyovskaya St. 18, Kazan, 420008, Russia \\ ${ }^{2}$ Lomonosov Moscow State University, Leninskie Gory, 1, Moscow, 119991, Russia \\ Correspondence to: Valentin Golosov (gollossov@gmail.com) and Artem Gusarov (avgusarov@mail.ru) \\ Published: 3 March 2017
}

\begin{abstract}
The Russian Plain (RP) is divided into two principally different parts. The northern half of the RP is a predominantly forested area with a low proportion of arable fields. In contrast, the southern half of the RP has a very high proportion of arable land. During the last 30 years, this agricultural region of the RP has experienced considerable land use transformation and changes in precipitation due to climate change have altered soil erosion rates. This paper describes the use of erosion model calculations and GIS spatial analytical methods for the evaluation of trends in erosion rates in the RP. Climate change (RIHMI World Data Center, 2016), land use transformation and crop rotation modification (Rosstat, 2016; R Core Team, 2016) are the main factors governing erosion rates in the region during recent decades. It was determined that mean annual erosion rates have decreased from 7.3 to $4.1 \mathrm{tha}^{-1} \mathrm{yr}^{-1}$ in the forest zone mostly because of the serious reduction in the surface runoff coefficient for periods of snowmelt. At the same time, the erosion rates have increased from 3.9 to $4.6 \mathrm{tha}^{-1} \mathrm{yr}^{-1}$ in the steppe zone due to the increasing frequency of heavy rain-storms.
\end{abstract}

1

\section{Introduction}

The southern part of the RP has very fertile soils and is the largest agricultural region in Europe. This physiographic region consists of forest, forest-steppe and steppe landscape zones. Agricultural activity in the region has varied in duration from 4-5 centuries in the central region around Moscow in the forest zone to about $120-150$ years in the south and south-east within the steppe zones (Sidorchuk and Golosov, 2003). The largest area of agricultural activity is located in the forest-steppe zone. During the 20th century, the spatial extent of agricultural activity was relatively stable within the forest and forest-steppe zone. However, it expanded in the steppe zone up to the end of the 1950s.

The last national scale quantitative assessment of erosion rates for the European part of Russia (ER) was conducted in the 1980s using a modified version of the USLE and the State Hydrological Institute model for soil erosion during periods of rain-fall and snowmelt (Larionov, 1993). Results from the model were verified using monitoring data for soil losses dur- ing snowmelt and total sedimentation in the small field ponds constructed in the early 1970's (Golosov, 2006). Estimates from the model agreed favourably with measured soil loss.

More than 35 years have passed since the last quantitative assessment of soil erosion losses from croplands on the RP. Considerable economic changes have occurred since the collapse of the USSR in 1991 and land use and crop-rotation changes in some landscape zones are evident. In addition, global warming has altered the rates and magnitude of precipitation (Groisman et al., 1999). While the effect of land use and climate change have influenced erosion rates in many parts of the World (Yang et al., 2003; Zhao et al., 2013) currently, there are no quantitative assessments of soil erosion rates in the southern portion of the predominantly agricultural RP. Because of its large spatial extent, such an assessment is only possible using a suite of remote-sensing and GIS spatial analytical methods coupled with erosion models. The methodology and initial results of this approach are presented herein to compare soil erosion rates with previous studies conducted in the 1980s. 

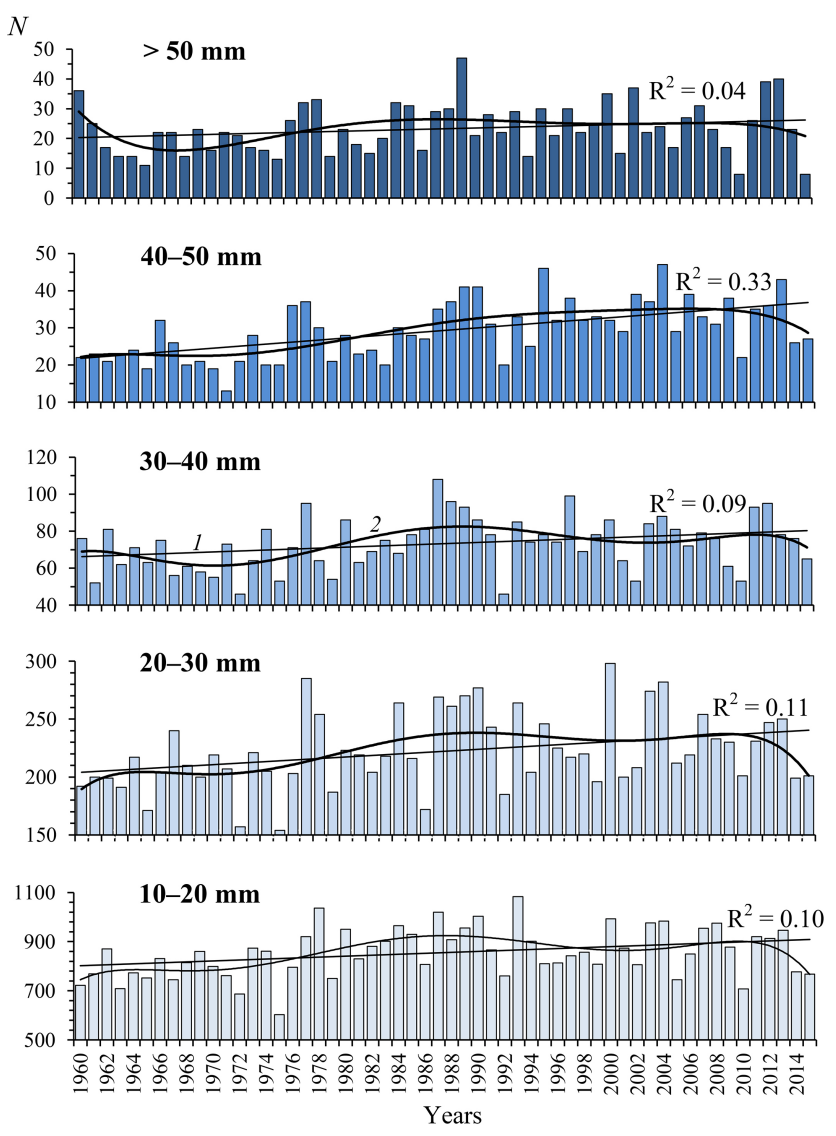

Figure 1. The mean annual number of days ( $N$, units) with different amounts of daily precipitation (warm season, May-September) for the period 1960-2015 for all 176 meteorological stations on the RP used in this analysis. 1 - linear trend, 2 - sixth-degree polynomial trend.

\section{Materials and methodology}

The assessment of trends in erosion rates for the entire area of the RP is based on analysis of the dynamics of the main meteorological parameters (Dore, 2005; Zolina, 2012) and changes in both crop area and type. Estimates of present-day erosion rates for different landscapes were compared to mean annual erosion rates estimated in the 1980s.

The key meteorological parameters determining the erosion rates are soil temperature (before the period of snowmelt) and number of rain events $>10 \mathrm{~mm}$. Soil temperature data for European Russia from 1960 (Park et al., 2014) was used in the models. Daily precipitation data were provided by the RIHMI World Data Center (http://aisori.meteo. ru/ClimateR; Veselov, 2002; Razuvaev et al., 1993). A total of 176 meteorological stations were selected for the analysis. The meteorological stations used in this study had precipitation data for the period 1960-2015 (several exceptions were made; a shift to 1966-2014 was accepted) and had no more than $10 \%$ of the time series missing. According to Zolina
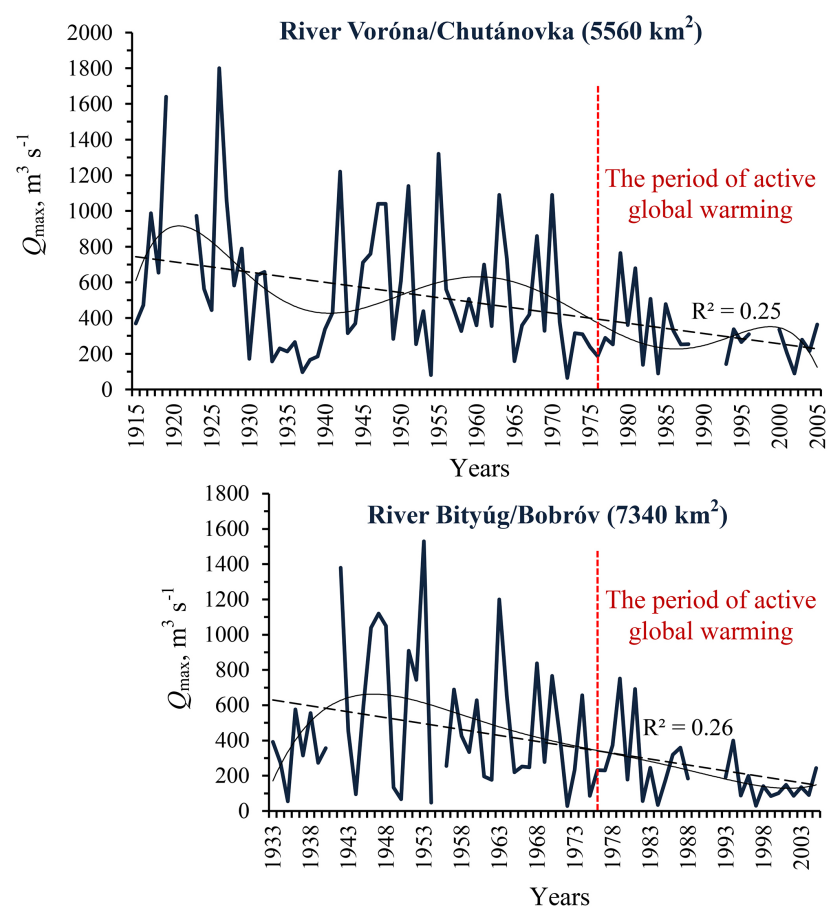

Figure 2. Trends in maximum water discharges $\left(Q_{\max }\right)$ during spring floods for some small rivers in the south of the forest-steppe zone of the RP.

(2012), it is appropriate to exclude stations where more than $20 \%$ of data set is missing. Rainfall measurements were categorized as >10, 10-20, 20-30, 30-40, 40-50 and >50 mm by total amount and frequency. The pattern of each time series was evaluated using a generalized linear model (Madsen and Thyregod, 2012). Data processing, model building, evaluation and visualization were performed in the " $\mathrm{R}$ environment" (R Core Team, 2016).

Data on land-use changes and the spatial extent of land area and crop type for different regions since 1991 were provided by the Russian Federal State Statistics Service (Rosstat, 2016). Particular attention was given to evaluation of cropland dynamics in each landscape zone. Additional sources of information for correction of possible errors in the official statistics were found elsewhere (Lyuri et al., 2010). Crop rotation coefficients for modelling were calculated separately for both rainfall season and snow melt for the period 1991-2014.

\section{Results}

There is widespread agreement in the literature that climate change has had a significant effect on weather patterns (Dore, 2005) and erosion rates globally (Nearing et al., 2004). The total number of rain events of $>10 \mathrm{~mm}$ have not increased significantly for all groups since the 1960s for most parts of the RP (Fig. 1). There was, however, a significant increase 
Table 1. Comparison of mean annual soil erosion rates and total soil losses between1980 and 2012.

\begin{tabular}{|c|c|c|c|c|c|c|}
\hline $\begin{array}{l}\text { Landscape zones (subzones) } \\
\text { of the European part of Russia } \\
\text { (without mountain areas) }\end{array}$ & $\begin{array}{l}\text { Mean annual } \\
\text { soil erosion rates } \\
\text { in } 1980 \text {, } \\
\text { tha }^{-1} \mathrm{yr}^{-1}\end{array}$ & $\begin{array}{l}\text { Mean annual } \\
\text { soil erosion } \\
\text { rates in } 2012 \text {, } \\
\text { tha }^{-1} \mathrm{yr}^{-1}\end{array}$ & $\begin{array}{l}\text { Change in } \\
\text { mean annual } \\
\text { soil erosion } \\
\text { rates }^{*},( \pm) \%\end{array}$ & $\begin{array}{l}\text { Total soil } \\
\text { losses } \\
\text { in } 1980 \text {, } \\
10^{3} \mathrm{t}\end{array}$ & $\begin{array}{l}\text { Total soil } \\
\text { losses } \\
\text { in } 2012 \text {, } \\
10^{3} \mathrm{t}\end{array}$ & $\begin{array}{l}\text { Change } \\
\text { in } \\
\text { total soil } \\
\text { losses* } \\
( \pm) \%\end{array}$ \\
\hline $\begin{array}{l}\text { Northern and middle } \\
\text { taiga subzones }\end{array}$ & 6.5 & 4.0 & -38.4 & 6131.5 & 1809 & -70.5 \\
\hline Southern taiga subzone & 7.3 & 4.1 & -44.0 & 145032 & 35966 & -75.2 \\
\hline Forest zones, total & 7.3 & 4.1 & -43.8 & 151163 & 37791 & -75.0 \\
\hline Forest-steppe zone & 4.1 & 3.3 & -19.4 & 136450 & 79277 & -41.9 \\
\hline Steppe zone & 3.9 & 4.63 & 18.7 & 148618 & 127663 & -14.1 \\
\hline Total European Russia & 4.7 & 4.0 & -15.0 & 436231 & 244831 & -43.9 \\
\hline
\end{tabular}

* relationship between 1980 and 2012

Table 2. Changes in the areas of arable and cultivated lands in the landscape zones of the RP between 1980 and 2012.

\begin{tabular}{|c|c|c|c|c|c|}
\hline \multirow[b]{2}{*}{$\begin{array}{l}\text { Landscape zones of the } \\
\text { European part of Russia }\end{array}$} & \multirow[b]{2}{*}{$\begin{array}{r}\text { Area of cultivated lands } \\
\text { in } 1980^{*}, \\
10^{3} \text { ha }\end{array}$} & \multirow[b]{2}{*}{$\begin{array}{r}\text { Arable lands } \\
\text { in } 2012, \\
10^{3} \text { ha }\end{array}$} & \multirow[b]{2}{*}{$\begin{array}{r}\text { Area of cultivated lands } \\
\text { in } 2012 \\
10^{3} \text { ha }\end{array}$} & \multicolumn{2}{|c|}{$\%$ Change in area } \\
\hline & & & & $\begin{array}{r}\text { Arable lands } \\
\text { in } 2012 \\
( \pm) \%\end{array}$ & $\begin{array}{r}\text { Area of cultivated lands } \\
\text { in } 2012 \\
( \pm) \%\end{array}$ \\
\hline Forest zones (total) & 20789.9 & 16738 & 9222.1 & -19.5 & -55.6 \\
\hline Forest-steppe zone & 33286.4 & 29360 & 23978.1 & -11.8 & -28 \\
\hline Steppe zone & 38544.8 & 36104 & 27894.3 & -6.3 & -27.6 \\
\hline Total European Russia & 92621.2 & 82202 & 61094.5 & -11.2 & -34 \\
\hline
\end{tabular}

* Area of cultivated lands in 1980 was equal to area of arable lands

$(p>0.10)$ in the number of rain events $>40-50 \mathrm{~mm}$ mostly along the line linking Bryansk-Izhevsk and near the Caucasus foothills in the south-west parts of the steppe zone. It has previously been reported that about $80 \%$ of total soil losses occur during the warm season (Edwards and Owens, 1991) and the observed increase in the total number of heavy rains will have had an effect on the erosion in the steppe zone of the RP (Table 1).

The average soil temperature increased over the period 1960 to 2006 by $8^{\circ} \mathrm{C}$ in the south-western part of the RP in the steppe zone and $4{ }^{\circ} \mathrm{C}$ in the southern part of the forest zone near the Ural mountain system (Park et al., 2014). Increasing soil temperature reduced the depth of frozen soil before snowmelt and surface runoff coefficients decreased as a consequence. This is also confirmed by a reduction in spring flood levels for most small rivers in the southern half of the RP since the beginning of the 1980s (Fig. 2). Results of direct monitoring of surface runoff from cultivated land at the Novosil' monitoring station, located in the middle part of the Zhusha River basin (Central Russia), confirmed that the coefficient of surface runoff had decreased from 0.5 for the period 1955-1980 to $<0.1$ for the most recent decades (Petelko et al., 2007). The observed decrease in gully head retreat rates during the last decade in different parts of the
Vyatsko-Kamskoe interfluve area may also account for the reduction of surface runoff from the cultivated slopes during periods of snowmelt (Rysin et al., this volume). Accordingly, soil losses from croplands during snowmelt periods have decreased significantly over the last two decades in particular in the forest zone.

During the period 1980-2012, there was a significant reduction in cropland area due to an increase in abandoned lands that have not been cultivated for the past decade for the all landscape zones of the RP (Table 2). However, the extent of cultivated lands has increased in the forest-steppe zone since 2010.

Although some changes in crop rotation were observed, the crop and cover management coefficients have not changed for the forest-steppe and steppe zones. However, crop and cover management coefficients have decreased in the forest zone. The primary reason for this observation was an increasing proportion of cultivated land under annual and/or perennial grasses in the forest landscape zone.

Meteorological and land use change data were used to recalculate the mean annual erosion rates and the annual soil losses for the different landscape zones of the RP (Table 1). It was found that the annual soil losses had decreased in all the landscape zones because of a reduction in cropland area. 
Further analyses of the factors affecting soil erosion rates at a range of spatial scales and for different landscape types is required to provide more detail regarding the influence of land use and climate change on the erosion rates in the agriculturally intensive southern portion of the RP.

\section{Conclusions}

Quantitative assessment of contemporary erosion rates on the arable lands of the RP was undertaken using remote sensing and GIS techniques coupled with erosion models. Temporal changes of some key parameters in the erosion model (erosion index of precipitation, crop and cover management coefficients and surface runoff coefficient for periods of snowmelt) were investigated. During the period from 1980 to 2012, mean annual erosion rates decreased from 7.3 to $4.1 \mathrm{tha}^{-1} \mathrm{yr}^{-1}$ in the forest zone, because of a reduction in surface runoff coefficients during snowmelt and the increasing area under annual and perennial grasses. There was a slight decrease in erosion rates in the forest-steppe zone and a more significant increase in erosion rates in the steppe zone (Table 1). The latter change occurred because of the increasing frequency of heavy rainstorms. The reduction in soil loss since the 1980s in all landscape zones was attributed to the decrease in cropped area (Table 2).

\section{Data availability}

Information about arable and cultivated lands was collected and areas under different crops (information was used for calculation of crop and cover management coefficients), were taken from the official site of Rosstat - Russian Federal Service of State Statistics, Moscow, Russia, available at: http://www.gks.ru (Rosstat, 2016). Additional sources of information for correction of possible errors in the official statistics for arable and cultivated lands were found in Lyuri et al. (2010). Meteorological information about daily precipitation data were provided by the RIHMI World Data Center (2016, http://aisori.meteo.ru/ClimateR). Information about soil characteristics and LS factor (relief factor), which are also requested for soil erosion rate calculation, were collected for the initial calculation of soil losses on period 1980 and it is only available in the form of paper worksheets. In the calculations of soil erosion rates, it was assumed that these parameters remain unchanged since 1980 until 2012. It is planned to consider possible changes to the relief factor due to changes in arable areas. Information about maximum water discharge were collected from Hydrological Yearbooks, which are available only in printed version and they are not publicly accessible since 1991, because of they collected by Hydrometeorological Service of Russian Federation and concentrated in State Hydrological Institute. It is possible to receive access to them only by official request.
Competing interests. The authors declare that they have no conflict of interest.

Acknowledgements. This work was funded by the Russian Science Foundation, project no. 15-17-20006.

\section{References}

Dore, M. H. I.: Climate change and changes in global precipitation patterns: what do we know?, Environ. Int., 31, 1167-1181, doi:10.1016/j.envint.2005.03.004, 2005.

Edwards, W. M. and Owens, I. B.: Large storm effects on the total soil erosion, J. Soil Water Conserv., 46, 75-78, 1991.

Golosov, V. N.: Erozionno-akkumulyativnye protsessi v rechnih basseinah osvoennih ravnin (Erosion and deposition processes in river basins of cultivated plains), Moscow: GEOS (Publ.), 296 pp., 2006 (in Russian).

Groisman, P. Y., Karl, T. R., Easterling, D. R., Knight, R. W., Jamason, P. F., Henessy, K. J., Suppiah, R., Page, C. M., Wibig, J., Fortuniak, K., Razuvaev, V. N., Douglas, A., Forland, E., and Zhai, P. M.: Changes in the probability of heavy precipitation: important indicators of climatic change, Climatic Change, 42, 243-285, doi:10.1023/A:1005432803188, 1999.

Larionov, G. A.: Vodnaya i vetrovaya eroziya: osnovnye zakonomernosti i kolichestvennaya otsenka (Water and wind erosion: main features and quantitative assessment), Moscow: MGU (Publ), 200 pp., 1993 (in Russian).

Lyuri, D. I., Goryachkin, S. V., Karavaeva, N. A., Denisenko, E. A., and Nefedova, T. G.: Dinamika selskohoziaystvennih zemel' v Rossii v XX veke i postagrogennoye vosstanovleniye rastitelnosti i pochv (Dynamics of agricultural lands in Russia in XX century and postagrogenic restoration of vegetation and soils), Moscow: GEOS (Publ.), 416 pp., 2010 (in Russian).

Madsen, H. and Thyregod, P.: Introduction to General and Generalized Linear Models. Chapman \& Hall/CRC, 2011.

Nearing, M. A., Pruski, F. F., and O’Neal, M. R.: Expected climate change impacts on soil erosion rates: A review, J. Soil Water Conserv., 59, 43-50, 2004.

Park, H., Sherstiukov, A. B., Fedorov, A. N., Polyakov, I. V., and Walsh, J. E.: An observation-based assessment of the influences of air temperature and snow depth on soil temperature in Russia, Environ. Res. Lett., 9, 1-7, doi:10.1088/1748-9326/9/6/064026, 2014.

Petelko, A. I., Golosov, V. N., and Belyaev, V. R.: Experience of design of system of counter-erosion measures, Proceedings of the 10-th International Symposium on River Sedimentation, Moscow, 1, 311-316, 2007.

R Core Team: R: A language and environment for statistical computing, R Foundation for Statistical Computing, Vienna, Austria, available at: https://www.R-project.org, last access: February 2016.

Razuvayev, V. N., Apasova, E. G., Martuganov, R. A., Steurer, P., and Vose, R.: Daily Temperature and Precipitation Data for 223 U.S.S.R. Stations. ORNL/CDIAC, Numerical data package - 040, Oak Ridge National laboratory, Oak Ridge, Tennessee, USA, 1993. 
Russian Research Institute of Hydrometeorological Information World Data Center (RRIHI-WDS), Obninsk, Russia, available at: http://aisori.meteo.ru/ClimateR, last access: March 2016.

Rosstat - Russian Federal State statistics service (Rosstat-RFSSS), Moscow, Russia, available at: http://www.gks.ru, last access: March 2016.

Rysin, I. I., Grigoriev, I. I., Zaitseva, M. Yu., Golosov, V. N., and Sharifullin, A. G.: Long-term monitoring of gully erosion in Udmurt Republic, Proc. IAHS, in press, 2017.

Sidorchuk, A. Yu. and Golosov, V. N.: Erosion and sedimentation processes on the Russian plain, II: The history of erosion and sedimentation during the period of intensive agriculture, Hydrol. Process., 17, 3347-3358, doi:10.1002/hyp.1391, 2003.
Veselov, V. M.: PC archives of the State Data Holding and technology of their organization, Proceedings of RIHMI-WDC, 170, 16-30, 2002 (in Russian).

Zhao, G., Mu, X., Wen, Z., Wang, F., and Gao, P.: Soil erosion, conservation, and eco-environment changes in the Loess Plateau of China, Land Degrad. Dev., 24, 499-510, 2013.

Zolina, O.: Change in intense precipitation in Europe, in: Changes in Flood Risk in Europe, edited by: Kundzewicz, Z. W., IAHS Press, Wallingford, Oxfordshire, UK, Special issue no. 10, $97-$ 120, 2012.

Yang, D. W., Kanae, S., Oki, T., Koike, T., and Musiake, K.: Global potential soil erosion with reference to land use and climate changes, Hydrol. Process., 17, 2913-2928, 2003. 